\title{
Visible and near-infrared reflectivity during the ablation period on Peyto Glacier, Alberta, Canada
}

\author{
Paul M. Gutler* and D. Scott Munro \\ Department of Geography, University of Toronto, Erindale College, Mississauga, Ontario L5L 1C6, Canada
}

\begin{abstract}
Models for calculating glacier mass balance are sensitive to surface reflectivity variation. Fieldwork carried out on Peyto Glacier, Alberta, Canada, contributes to the data set available for ice-reflectivity parameterization in such models. Hemispherical reflectivity in the visible and near-infrared parts of the solar spectrum was obtained for rock, snow and three contrasting glacier surfaces to examine temporal and spatial variations. Glacier-ice near-infrared reflectivity displays only minor spatial variation $(0.12-0.17)$ in comparison with the visible range $(0.23-$ $0.40)$, the latter being influenced primarily by surface impurity content. Surface roughness is of minor importance compared with impurities. Temporal variation of reflectivity was weak at all glacier-ice and rock locations; slight variations observed were due to changes in either solar zenith angle or cloud amount. Snow reflectivity displayed pronounced diurnal asymmetry and a larger response to cloud cover. The minimal temporal variation in glacier-ice reflectivity simplifies its parameterization. This behaviour is additionally useful for satellite-based measurements of the reflectivity field on larger glaciers, as images obtained within a $6 \mathrm{~h}$ window centred on solar noon are likely to yield values which are within $2-3 \%$ of daily mean values.
\end{abstract}

\section{INTRODUCTION}

The ablation areas of mid-latitude glaciers contribute a disproportionately large volume of meltwater to total summer discharge in proglacial streams. Differential reflection of incident solar radiation by the variety of surfaces encountered on valley glaciers exerts an important temporal and spatial control on meltwater generation. Whilst snow reflectivity has received extensive examination, in terms of both measurement and modelling (see reviews by Mellor, 1977; Warren, 1982; Dozier, 1987), exposed glacier ice remains underexplored in this regard. Meteorological investigations on glaciers have included the measurement of ice reflectivity, with considerable variation in the results obtained Andrews, 1964; Holmgren, 1971; Wendler and Weller, 1974). In light of the sensitivity of current glacier mass-balance simulations to reflectivity (Oerlemans and Hoogendoorn, 1989; Munro, 1991), estimating a single value from such studies to represent the entire ablation area of a new area will produce erroneous predictions of daily mass loss.

Fieldwork on Peyto Glacier, Alberta, Canada, was designed to quantify the spatial and temporal range of reflectivity in a temperate glacier setting. Snow reflectivity parameterizations in some current global circulation

\footnotetext{
* Now at the Department of Geology and Geophysics, University of Minnesota, 310 Pillsbury Drive SE, Minneapolis, MN 55455-0219, U.S.A.
}

models separate the visible and near-infrared wavebands (Marshall and Warren, 1987) because of their different responses to surface physical properties. Values from Peyto Glacier were obtained for the spectral wavebands of 0.35 $0.695 \mu \mathrm{m}$ (visible) and $0.695-2.8 \mu \mathrm{m}$ (near-infrared).

\section{BACKGROUND}

Measurements of broad-band reflectivity are often conducted over the short-wave spectrum from 0.35 to $2.8 \mu \mathrm{m}$, and are commonly referred to as albedo $(\rho)$. Hemispherical reflectivity over the broad visible and near-infrared spectral bands $\left(\rho_{\text {VIS }}\right.$ and $\left.\rho_{\text {NIR }}\right)$ is reported in this paper. The terminology adopted here originates from the more precise definitions of Siegel and Howell (1972).

Early measurements of $\rho$ on mid-latitude glaciers in the Austrian Alps were carried out by Sauberer and Dirmhirn (1952), Scheibbner and Mahringer (1968) and Wagner (1979). Table 1 includes results of these studies in a comparison of the quoted ranges of $\rho$ for different snow and ice surfaces. Grenfell and Perovich (1984) provided values for spectral reflectivity of glacier ice between 0.38 and $2.5 \mu \mathrm{m}$ for Athabasca Glacier, Canada. Munro and Young (1982) made some preliminary investigations of $\rho$ on Peyto Glacier.

The factors influencing reflectivity are those related to the surface itself and those concerning the incident solar radiation. An increase in grain-size results in reduced reflectivity, most effectively in the near-infrared spectral region (Warren, 1982). Bohren and Beschta (1979) 
Table 1. Examples of reported ranges of total hemispherical reflectivity over glacier surfaces. Surface descriptions are adapted from those used by the authors cited in the table

Source

Wagner (1979)

Scheibbner and Mahringer

Markin (1961)

Sauberer and Dirmhirn

(1968)

(1952)

Location

Hintereistemer

Sonnblickgletscher

Franz-Josef Land

Sonnblickgletscher

New snow $(>0.05 \mathrm{~m}$ thick)

New snow $(<0.05 \mathrm{~m}$ thick)

Glean old snow

Impure old snow

Clean firn

Impure firn

Clean ice

Medium impure ice

Impure ice

$\begin{array}{cc}0.90-0.95 & - \\ 0.60-0.90 & 0.70-0.88 \\ 0.62-0.68 & 0.50-0.70 \\ 0.46-0.59 & 0.35-0.50 \\ - & 0.50-0.63 \\ 0.25-0.30 & 0.15-0.30 \\ - & 0.30-0.45 \\ 0.15-0.20 & 0.20-0.30 \\ - & 0.06-0.20\end{array}$

$0.90-0.95$

$0.62-0.68$

$-$

$0.88-0.98$
$0.85-0.95$
$0.65-0.70$
$\quad-$
$0.60-0.65$
$\quad-$
-
-
-

$0.70-0.90$

$0.46-0.70$

$0.30-0.60$

$0.50-0.65$

$0.18-0.30$

$0.30-0.46$

$0.20-0.30$

$0.09-0.20$ demonstrated that for a given grain-size $\rho$ is, at most, weakly dependent on density. Water alone does not increase radiation absorption, because its refractive index is similar to that of ice (Bergen and others, 1983), but the effective grain-size is increased by water in interstices between grains (Colbeck, 1979), and this reduces $\rho$. Impurity content acts mainly on visible reflectivity; larger concentrations reduce values of $\rho$ (Warren, 1982). Increasing surface roughness, through the development of microtopographical features such as sastrugi, has the same effect. Slope angle and aspect interact with incident solar-radiation geometry to alter its effective angle of approach to the surface, thus altering $\rho$ (Mannstein, 1985). A dependence of reflectivity on solar zenith angle, $\theta$, has been demonstrated in numerous studies over snow and ice (Sauberer and Dirmhirn, 1952; Hubley, 1955; Scheibbner and Mahringer, 1968; Yamanouchi, 1983; McGuffie and Henderson-Sellers, 1985; Wendler and Kelley, 1988), where reflectivity increases as $\theta$ increases, because of enhanced specular reflection of the directbeam component of radiation.

The spectral composition of incident solar radiation is altered by the presence of clouds as water and ice preferentially absorb near-infrared radiation, thus increasing the proportion of visible light. This enhances $\rho$ because snow and ice reflect more visible than nearinfrared radiation (Warren, 1982). Additionally, the diffuse fraction of the incident flux increases with cloud cover. The diurnal variation of $\rho$ is smoothed as the diffuse fraction increases, with values for $\theta>50^{\circ}$ reduced but those for $\theta<50^{\circ}$ increased, a response which has been well documented for water (Nunez and others, 1972).

\section{PROCEDURES}

Five sites in the ablation zone of Peyto Glacier were examined, each for approximately 1 week of the 1990 summer. Three locations were chosen to represent extremes of clean, dirty and rough ice (excluding crevassed areas). The remaining two sites were on melting snow and rock. A detailed assessment of surface properties was carried out for each site (Table 2).
Impurity content was determined by filtering a melted sample of known volume through a pre-weighed quartz membrane filter $(1.5 \mu \mathrm{m}$ pore spacing). The sample was then dried for $24 \mathrm{~h}$ at $110^{\circ} \mathrm{C}$ and reweighed to yield impurity content. Snow density was measured using standard techniques (Ostrem and Brugman, 1991). Values for ice were obtained from a SIPRE-type coring auger $(83 \mathrm{~mm}$ diameter) penetrating the topmost 0.25 $0.30 \mathrm{~m}$ of the surface. Each sample was split at the discontinuity between the weathering crust (Müller and Keeler, 1969) and the more dense ice below, permitting separate densities to be calculated. Surface roughness at each site was estimated by laying out $5 \mathrm{~m}$ long poles on the ice and measuring the distance from pole to surface at $0.1 \mathrm{~m}$ intervals. Five hundred values were collected along each of two transects aligned at right-angles to one another, and standard deviation about the mean distance was used as an index of roughness.

Four pyranometers (Kipp and Zonen, Model CM11, Holland) were used to obtain hemispherical reflectivity. These were mounted in two back-to-back pairs on adjacent horizontal supporting arms $1.6 \mathrm{~m}$ above the surface. One pair recorded incoming and reflected solar radiation over that part of the spectrum which passes through clear glass $(0.35-2.8 \mu \mathrm{m})$, thus capturing all but negligible amounts of solar radiation $(K)$ from the full short-wave spectrum. Hemispherical RG695 filters on the second pair permitted only wavelengths greater than $0.695 \mu \mathrm{m}$ to pass through, thus capturing near-infrared solar radiation $\left(K_{\mathrm{NIR}}\right)$. Then $\rho_{\mathrm{VIS}}$ and $\rho_{\mathrm{NIR}}$ are estimated by:

$$
\begin{aligned}
\rho_{\mathrm{VIS}}= & \frac{\int_{0.35}^{0.695} \rho_{\lambda} K_{\lambda} \mathrm{d} \lambda}{\int_{0.35}^{0.695} K_{\lambda} \mathrm{d} \lambda}=\frac{K \uparrow-K \uparrow_{\mathrm{NIR}}}{K \downarrow-K \downarrow_{\mathrm{NIR}}} \\
\rho_{\mathrm{NIR}}= & \frac{\int_{0.695}^{2.8} \rho_{\lambda} K_{\lambda} \mathrm{d} \lambda}{\int_{0.695}^{2.8} K_{\lambda} \mathrm{d} \lambda}=\frac{K \uparrow_{\mathrm{NIR}}}{K \downarrow_{\mathrm{NIR}}}
\end{aligned}
$$

where $\lambda$ refers to wavelength and arrows denote directions of flux. 


\begin{tabular}{|c|c|c|c|c|c|c|}
\hline Site & Units & Snow & Dirty ice & Clean ice & Hummocky ice & Moraine \\
\hline Measurement period & Julian days & $203-210$ & $210-217$ & $217-223$ & $223-232$ & $198-203$ \\
\hline Elevation & $\mathrm{m}$ & 2500 & 2267 & 2265 & 2244 & 2240 \\
\hline Aspect & $\circ$ & 032 & 350 & 350 & $107,287^{7}$ & 315 \\
\hline Inclination & $\circ$ & 09 & 04 & 02 & $30-48$ & 07 \\
\hline \multicolumn{7}{|c|}{ Surface impurity content ${ }^{1}$} \\
\hline Maximum $^{2}$ & $\mathrm{gl}^{-1}$ & $0.199 \pm 0.040$ & $2.911 \pm 1.354$ & $1.390 \pm 0.626$ & $2.475 \pm 1.976$ & - \\
\hline Minimum $^{3}$ & $\mathrm{gl}^{-1}$ & & $1.598 \pm 0.253$ & $0.151 \pm 0.088$ & $0.197 \pm 0.079$ & - \\
\hline \multicolumn{7}{|c|}{ 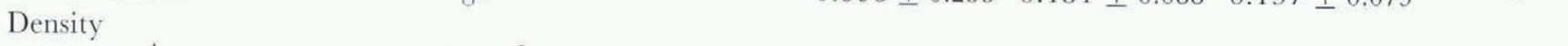 } \\
\hline Surface $^{4}$ & $\mathrm{~kg} \mathrm{~m}^{3}$ & $515 \pm 13$ & $671 \pm 21$ & $630 \pm 31$ & $613 \pm 41$ & - \\
\hline Substrate ${ }^{5}$ & $\mathrm{~kg} \mathrm{~m}^{-3}$ & $569 \pm 12$ & $822 \pm 28$ & $834 \pm 23$ & $834 \pm 27$ & \\
\hline \multicolumn{7}{|l|}{ Roughness $^{6}$} \\
\hline East-west & $\mathrm{mm}$ & 30 & 89 & 113 & 163 & 50 \\
\hline North-south & $\mathrm{mm}$ & 27 & 44 & 72 & 30 & 44 \\
\hline Grain-size & $\mathrm{mm}$ & $0.75-1.00$ & $5-30$ & $5-30$ & $5-20$ & $5-400$ \\
\hline
\end{tabular}

${ }^{1}$ From the top $10 \mathrm{~mm}$.

${ }^{2}$ Mean of three highest values.

${ }^{3}$ Mean of three lowest values.

${ }^{4}$ To a depth of $609 \mathrm{~mm}$.

${ }^{5}$ Layer immediately below surface sample to a depth of $0.3 \mathrm{~m}$.

It was important to maintain constant sensor height in order to eliminate changes in the field of view of the inverted instruments. A "floating" support system was thus adopted in which a vertical mast rested on a small flat rock $\left(0.05 \mathrm{~m}^{2}\right.$ in area) on the glacier surface. A bolt embedded in the rock held the pole centred, while three guy wires provided the necessary stability. The system performed well throughout the season, with minimal adjustment. The pyranometers were aligned such that midday shadows were cast north of the centre of the inverted-pyranometer viewing circle.

The percentage of total reflected solar radiation $\left(F_{a}\right)$ originating from a circle of radius $a$ can be calculated from instrument height $Z_{0}$ (Schwerdtfeger, 1976):

$$
F_{a}=\frac{a^{2}}{a^{2}+Z_{0}^{2}} .
$$

Sensors mounted at $1.6 \mathrm{~m}$ would therefore receive $91 \%$ of their signal from within a circle of radius $5 \mathrm{~m}$. Accordingly, observations of surface physical properties were made within this boundary whenever possible.

The pyranometer signals were scanned at $5 \mathrm{~s}$ intervals by a data logger Campbell Scientific, Model 21X. U.S.A.) which recorded $15 \mathrm{~min}$ mean values. A number of adjustments were made to the data:

(i) A filter factor of 1.049 was applied to the sensors fitted with RG695 filters to correct for solar radiation absorbed by the glass.

(ii) A correction factor of 1.01 , based on measurements of shaded area over a range of solar zenith angles, was applied to data from the inverted sensors.

(iii) Data obtained during precipitation periods were
${ }^{6}$ Standard deviation of 500 readings in east-west and north-south transects.

${ }^{7}$ Aspects represent two dominant slopes of the hummocked surface, $180^{\circ}$ apart.

discarded, since the presence of raindrops on the inverted glass hemispheres may have produced erroneous readings.

Consideration of potential errors in pyranometric measurements, treating them as independent and additive, results in a worst-case error of $\pm 5.4 \%$ for the reflectivity measurements. McGuffie and Henderson-Sellers (1985) point out that this range is broad enough to mask many of the subtle variations in reflectivity that are sought. This is, however, not thought to be a problem since the errors represent the mean deviation from the correct reading, the direction of which is unlikely to change over the day, or from one day to the next. Experiments performed on the inverted instruments, to investigate possible alteration in calibration constant due to overturning, showed no significant effect upon the calibration.

Data from the upward-facing unfiltered pyranometer were used, in conjunction with pyrheliometric measurements of direct radiation (Epply, Model E6, U.S.A.) to find the diffuse radiation, $D$, by residual. Thus, a statistical relationship was found between global radiation, and the diffuse fraction:

$$
\frac{D}{K \downarrow}=\alpha+\beta \frac{K \downarrow}{I_{0} \cos \theta}
$$

where $I_{0}$, the solar constant, is taken to be $1353 \mathrm{Wm}^{-2}$ (Monteith, 1973) and $\theta$ is the solar zenith angle. Our data yielded $\alpha=1.171$ and $\beta=-1.225$, with a coefficient of determination equal to 0.82 . It should be noted that the diffuse fraction is assumed to be equal in the visible and near-infrared spectral regions in later data analysis. Commonly the diffuse-radiation peak drifts further into the near-infrared as cloud increases (Weiss and Norman, 1985 ). 


\section{RESULTS AND DISCUSSION}

A strong distinction between $\rho_{\mathrm{VIS}}$ and $\rho_{\mathrm{NIR}}$ was observed under clear skies at all three glacier-ice locations (Fig. 1a). The larger values for $\rho_{\text {VIS }}$ agree with previously observed contrasts between the two wavebands over snow surfaces. The large surface impurity content at the dirtyice site is responsible for the relatively greater difference between $\rho_{\mathrm{VIS}}$ and $\rho_{\mathrm{NIR}}$ at this site. Reflectivity displayed limited temporal variation, whilst spatial variation, indicated by comparing the clean-ice and dirty-ice results, was markedly larger in the visible spectral range. The presence of surface roughness elements at the hummocky-ice site, creating microtopographic shading, is apparently less influential than impurity content. Evidence for asymmetry of $\rho_{\mathrm{VIS}}$ and $\rho_{\mathrm{NIR}}$ around solar noon, caused by physical changes of the surface over the passage of a day (melting), was only slight, although afternoon values tend to be lower than mid-morning values at the hummocky- and dirty-ice sites.

Snow cover and rock are at the extremes of the range of observed reflectivity behaviour (Fig. 1b). The greater diurnal variation of reflectivities occurred at the snow site.

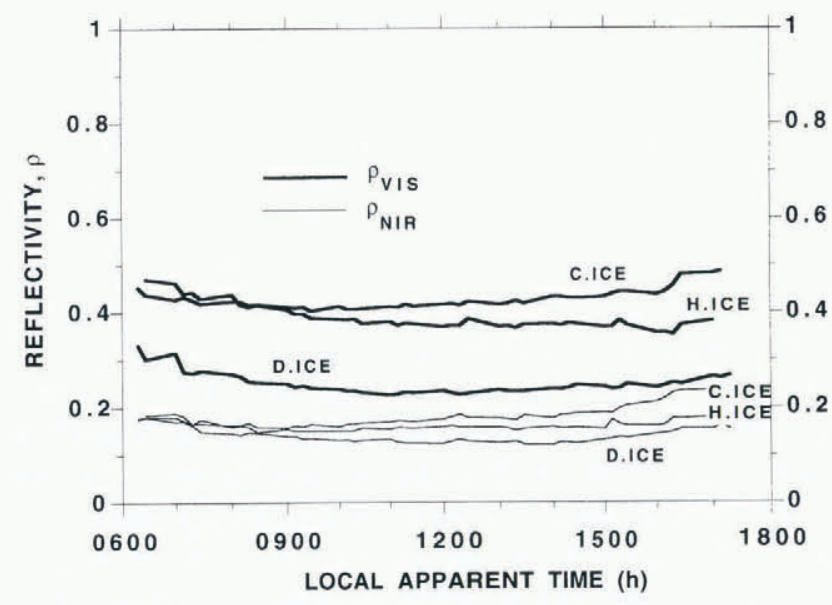

a

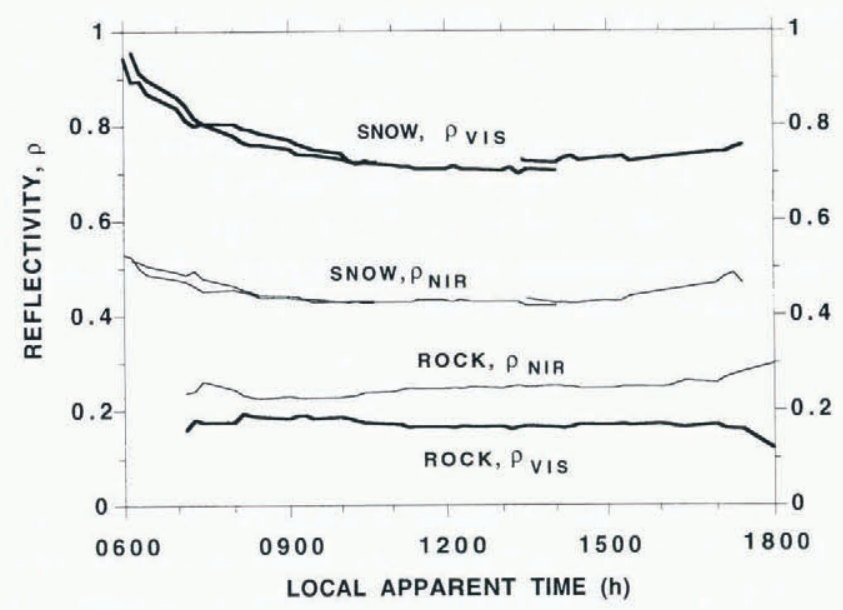

b

Fig. 1. (a) Diurnal variation of $\rho_{\mathrm{VIS}}$ and $\rho_{\mathrm{NIR}}$ on clear days at the dirty-ice (D.ICE), clean-ice (C.ICE) and hummocked-ice (H.ICE) sites. (b) Diumal variation of $\rho_{\mathrm{VIS}}$ and $\rho_{\mathrm{NIR}}$ on clear days at the snow and rock sites.
As no completely clear days occurred during the snow measurements period, a composite trace was plotted by combining records from two days with overlapping clear periods. Here asymmetry around solar noon is more pronounced, with reduced afternoon values attributable to surface metamorphosis and slope geometry; the slope dips at $9^{\circ}$ west $\left(280^{\circ}\right)$, which favours greater reflection in the morning. In contrast to the glacier surfaces, reflection of solar radiation from rock is greater in the near-infrared range. Non-linearities in the traces are probably caused by shading effects from individual rock elements. As expected from an opaque medium, diurnal variation is negligible.

In order to study the influence of cloud cover on $\rho_{\mathrm{VIS}}$ and $\rho_{\text {NIR }}$, reflectivities recorded in the zenith-angle ranges $35^{\circ}<\theta<45^{\circ}$, and $50^{\circ}<\theta<60^{\circ}$ were plotted against the diffuse fraction of incident solar radiation, $D / K \downarrow$, an approach used by Nunez and others (1972) over water. As noted earlier, the presence of cloud should subdue reflectivity for $\theta>50^{\circ}$, whilst the converse is expected for $\theta<50^{\circ}$.

The results of this analysis (Fig. 2) for dirty ice, in the zenith-angle range $35^{\circ}<\theta<45^{\circ}$, show that neither waveband is particularly sensitive to increasing diffuse fraction, although there is a rising trend which is quantified by regressing reflectivity against diffuse fraction of incident global radiation (Table 3). For dirty ice in the zenith-angle range $35^{\circ}<\theta<45^{\circ}, \rho_{\text {VIS }}$ rises by 0.033 as diffuse fraction goes from 0 to 1 , whereas $\rho_{\text {VIS }}$ increases by only 0.011 . Reflectivity for all glacier-ice sites shows a similarly weak response to increased diffuse fraction, although of the two wavebands the near-infrared shows the greater sensitivity. It should be noted that the standard error displayed in Table 3 is often $>50 \%$ of the change in reflectivity from purely direct to purely diffuse conditions.

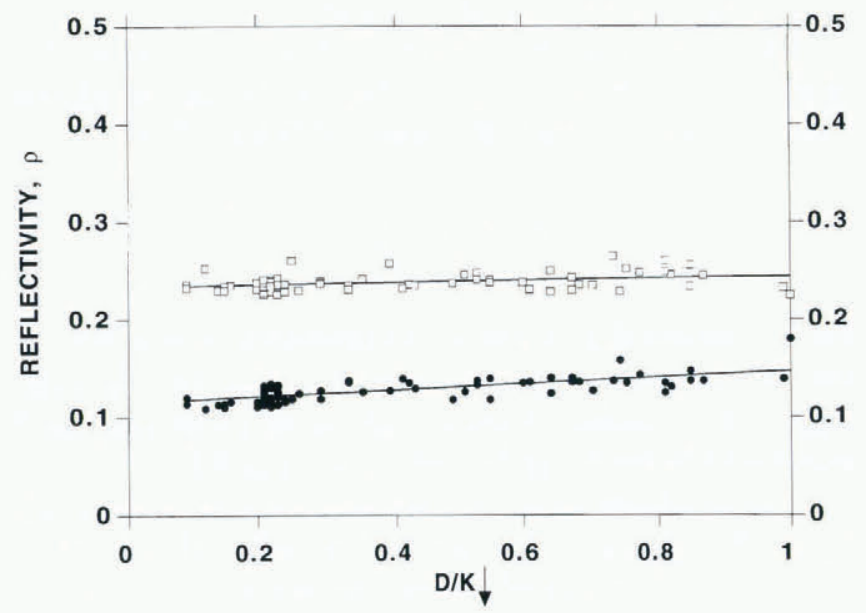

Fig. 2. The responses of $\rho_{\mathrm{VIS}}$ (open squares) and $\rho_{\mathrm{NIR}}$ (closed circles) at the dirty-ice site to increasing diffuse fraction of incident solar radiation for $35^{\circ}<\theta<45^{\circ}$.

As theory predicts (Choudhury and Chang, 1981), snow reflectivity under clear skies $(D / K \downarrow \rightarrow 0)$ is greater for the larger of the two $\theta$ ranges, so there is a more dramatic response of snow reflectivity to cloud (Fig. 3). 
Table 3. Results of linear regression analysis of reflectivity vs diffuse fraction of incident solar radiation

\begin{tabular}{|c|c|c|c|c|c|c|c|}
\hline Site & $\begin{array}{l}\text { Reflectivity } \\
\text { type }\end{array}$ & $\begin{array}{c}\text { Range of } \theta \\
\left({ }^{\circ}\right)\end{array}$ & Sample size & $\begin{array}{l}\text { Regression } \\
\text { slope }\end{array}$ & $\begin{array}{l}\text { Standard } \\
\text { error }\end{array}$ & $\begin{array}{c}\text { Reflectivity al } \\
D / K \downarrow=0\end{array}$ & $\begin{array}{c}\text { Reflectivity at } \\
D / K \downarrow=1\end{array}$ \\
\hline \multirow[t]{2}{*}{ Dirty ice } & $\rho_{\mathrm{VIS}}$ & $\begin{array}{l}35-45 \\
50-60\end{array}$ & $\begin{array}{l}71 \\
53\end{array}$ & $\begin{array}{r}0.011 \\
-0.002\end{array}$ & $\begin{array}{l}0.008 \\
0.013\end{array}$ & $\begin{array}{l}0.234 \\
0.253\end{array}$ & $\begin{array}{l}0.245 \\
0.250\end{array}$ \\
\hline & $\rho_{\mathrm{NIR}}$ & $\begin{array}{l}35-45 \\
50-60\end{array}$ & $\begin{array}{l}71 \\
53\end{array}$ & $\begin{array}{l}0.033 \\
0.033\end{array}$ & $\begin{array}{l}0.008 \\
0.012\end{array}$ & $\begin{array}{l}0.115 \\
0.125\end{array}$ & $\begin{array}{l}0.147 \\
0.158\end{array}$ \\
\hline \multirow[t]{2}{*}{ Clean ice } & $\rho_{\text {VIS }}$ & $\begin{array}{l}35-45 \\
50-60\end{array}$ & $\begin{array}{r}115 \\
54\end{array}$ & $\begin{array}{r}0.000 \\
-0.003\end{array}$ & $\begin{array}{l}0.009 \\
0.015\end{array}$ & $\begin{array}{l}0.406 \\
0.417\end{array}$ & $\begin{array}{l}0.406 \\
0.413\end{array}$ \\
\hline & $\rho_{\mathrm{NIR}}$ & $\begin{array}{l}35-45 \\
50-60\end{array}$ & $\begin{array}{r}115 \\
54\end{array}$ & $\begin{array}{l}0.023 \\
0.057\end{array}$ & $\begin{array}{l}0.014 \\
0.018\end{array}$ & $\begin{array}{l}0.164 \\
0.160\end{array}$ & $\begin{array}{l}0.187 \\
0.216\end{array}$ \\
\hline \multirow[t]{2}{*}{ Hummocked ice } & $\rho_{\mathrm{VIS}}$ & $\begin{array}{l}35-45 \\
50-60\end{array}$ & $\begin{array}{r}144 \\
74\end{array}$ & $\begin{array}{r}0.021 \\
-0.012\end{array}$ & $\begin{array}{l}0.011 \\
0.019\end{array}$ & $\begin{array}{l}0.378 \\
0.412\end{array}$ & $\begin{array}{l}0.398 \\
0.401\end{array}$ \\
\hline & $\rho_{\mathrm{NIR}}$ & $\begin{array}{l}35-45 \\
50-60\end{array}$ & $\begin{array}{r}144 \\
74\end{array}$ & $\begin{array}{l}0.033 \\
0.027\end{array}$ & $\begin{array}{l}0.016 \\
0.021\end{array}$ & $\begin{array}{l}0.154 \\
0.161\end{array}$ & $\begin{array}{l}0.186 \\
0.188\end{array}$ \\
\hline \multirow[t]{2}{*}{ Snow } & $\rho_{\mathrm{VIS}}$ & $\begin{array}{l}35-45 \\
50-60\end{array}$ & $\begin{array}{l}61 \\
45\end{array}$ & $\begin{array}{r}0.049 \\
-0.014\end{array}$ & $\begin{array}{l}0.014 \\
0.022\end{array}$ & $\begin{array}{l}0.728 \\
0.779\end{array}$ & $\begin{array}{l}0.777 \\
0.766\end{array}$ \\
\hline & $\rho_{\mathrm{NIR}}$ & $\begin{array}{l}35-45 \\
50-60\end{array}$ & $\begin{array}{l}61 \\
45\end{array}$ & $\begin{array}{l}0.184 \\
0.166\end{array}$ & $\begin{array}{l}0.016 \\
0.017\end{array}$ & $\begin{array}{l}0.396 \\
0.399\end{array}$ & $\begin{array}{l}0.580 \\
0.565\end{array}$ \\
\hline \multirow[t]{2}{*}{ Rock } & $\rho_{\mathrm{VIS}}$ & $\begin{array}{l}35-45 \\
50-60\end{array}$ & $\begin{array}{l}38 \\
31\end{array}$ & $\begin{array}{l}-0.006 \\
-0.019\end{array}$ & $\begin{array}{l}0.011 \\
0.018\end{array}$ & $\begin{array}{l}0.171 \\
0.182\end{array}$ & $\begin{array}{l}0.165 \\
0.164\end{array}$ \\
\hline & $\rho_{\mathrm{NIR}}$ & $\begin{array}{l}35-45 \\
50-60\end{array}$ & $\begin{array}{l}38 \\
31\end{array}$ & $\begin{array}{r}0.008 \\
-0.004\end{array}$ & $\begin{array}{l}0.010 \\
0.013\end{array}$ & $\begin{array}{l}0.240 \\
0.247\end{array}$ & $\begin{array}{l}0.248 \\
0.243\end{array}$ \\
\hline
\end{tabular}

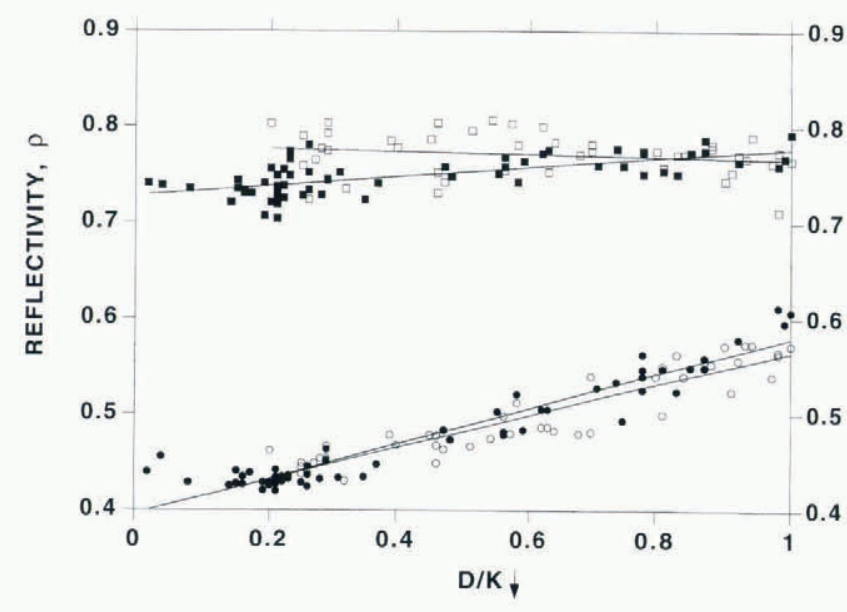

Fig. 3. The response of $\rho_{\mathrm{VIS}}$ (closed squares) and $\rho_{\mathrm{NIR}}$ (closed circles) at the metamorphosed snow site to increasing diffuse fraction of incident solar radiation for $35^{\circ}<\theta<45^{\circ}$, and equivalent responses for $50^{\circ}<\theta<60^{\circ}$ (open symbols).

Again $\rho_{\mathrm{NIR}}$ is the variable more sensitive to increasing diffuse fraction, and $\rho_{\mathrm{VIS}}$ provides a good example of how the two zenith-angle ranges may converge at $D / K \downarrow=1$ (as suggested by Nunez and others, 1972). These results indicate that most of the rise in $\rho$ under increasing cloud is due to the rise of reflectivity in the near-infrared part of the spectrum.
One factor driving changes in reflectivity under increasing cloud is diminished alteration of the angle of approach of incident solar radiation. It is therefore interesting to examine the relationship between reflectivity and $\cos \theta$ under sunny skies (Fig. 4), contrasting the behaviour of $\rho_{\mathrm{VIS}}$ and $\rho_{\mathrm{NIR}}$ at the clean-ice and the snow sites (clean ice was chosen because surface impurity content was the closest match with the snow site). Predominantly sunny sky prevails in the selected range

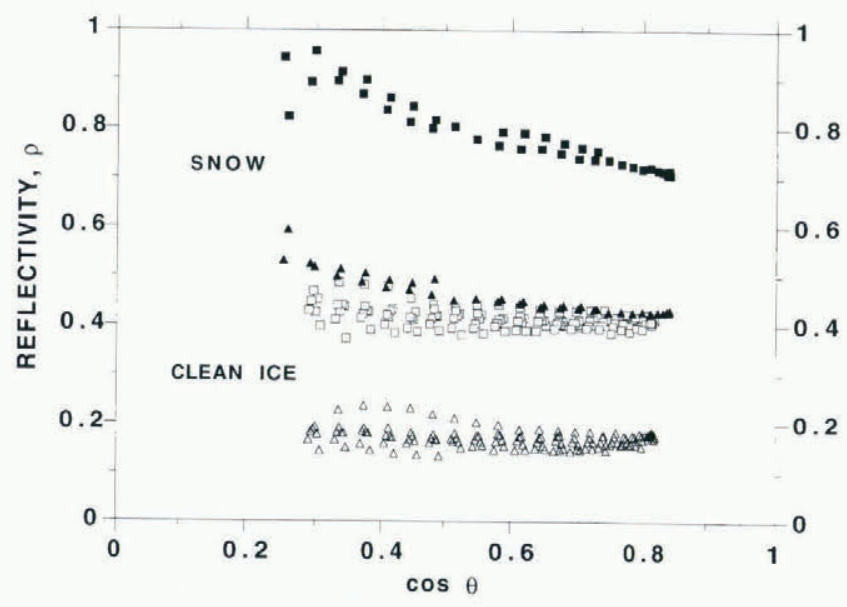

Fig. 4. The response of $\rho_{\mathrm{VIS}}$ (squares) and $\rho_{\mathrm{NIR}}$ (triangles) to increasing solar zenith angle at the sites for clean ice (open symbols) and snow (closed symbols). 
of cloud conditions ( $0-0.2$ cloud), thus minimizing the influence of cloud on $\theta$. As expected from the relatively greater response of the snow surface to cloud, the snow reflectivity displays the greater sensitivity to $\cos \theta$.

Direct comparison of our results with data sets from other glaciers is hindered by inadequate descriptions of surface properties in past investigations of reflectivity. The broad-band nature of our data also makes comparisons difficult because the majority of measurements available are spectral reflectivities for narrow wavebands. Nevertheless, comparison of our data with some spectral reflectivities published for glacier ice (Fig. 5) shows that $\rho_{\text {VIS }}$ for dirty ice (solar noon value) is slightly greater than values in the visible range reported by Zeng and others (1984) for what they term "honeycomb glacier ice". Their surface is interpreted as ice with multiple cryoconite holes containing morainic debris.

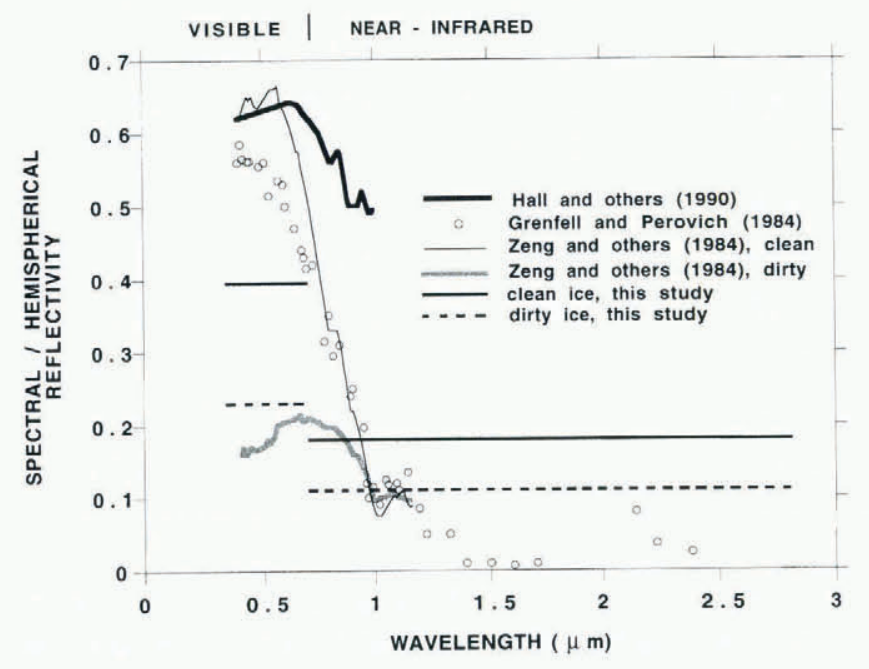

Fig. 5. Comparison of broad-band visible and nearinfrared reflectivities from clean and dirty glacier ice in this study with spectral reflectivity dala from other glacier-ice surfaces. The division between the visible and nearinfrared bands is indicated at the top of the figure.

Overall, it seems that the cleanest ice found on Peyto Glacier is surpassed on some glaciers. Comparison of $\rho_{\mathrm{VIS}}$ from the cleanest part of Peyto Glacier with spectral reflectivities of glacier ice (Fig. 5) suggests that surfaces examined by Grenfell and Perovich (1984), Zeng and others (1984) and Hall and others (1990) contained fewer impurities. The values of Zeng and others are for a blueice band, whilst Hall and others only describe their site as being in the ablation area.

Comparison of values in the near-infrared band is complicated by the rapid decrease in spectral reflectivities at $1.4 \mu \mathrm{m}$. Additionally, the spectral distribution of solar radiation may be slightly weighted towards the shorter wavelengths (Monteith, 1973; Weiss and Norman, 1985). Taking this into consideration, the data of Grenfell and Perovich, when weighted according to the expected distribution of incoming solar near-infrared radiation (Monteith, 1973), yield a value of 0.20 for the wavelength range equivalent to $\rho_{\mathrm{NIR}}$, which compares well with 0.18 for $\rho_{\mathrm{NIR}}$ at the clean-ice site.
For comparison of snow reflectivities with the literature, values are taken from solar noon under clearsky conditions $\left(\rho_{\mathrm{VIS}}=0.71, \rho_{\mathrm{NIR}}=0.42\right)$. Snow surface density obtained $1 \mathrm{~d}$ before the reflectivity measurements was $536 \pm 11 \mathrm{~kg} \mathrm{~m}^{-3}$. Laboratory tests were conducted by O'Brien and Munis (1975) for snow (density $525 \mathrm{~kg} \mathrm{~m}^{-3}$ ) over the wavelength range $0.6-2.5 \mu \mathrm{m}$. The range $0.6-$ $0.695 \mu \mathrm{m}$ lies in the visible region as defined by the present study. In this range, O'Brien and Munis observed reflectivities of 0.85 ; substantially higher than 0.71 for $\rho_{\text {VIS }}$. This is attributed to impurities in the natural surface on Peyto Glacier, as well as greater roughness. A comparable snow surface is reported by Grenfell and others (1981) with a density of $480 \mathrm{~kg} \mathrm{~m}^{-3}$ and an impurity content $<500 \mathrm{ppm}$ by mass. Visible spectral reflectivities ranged from 0.72 to 0.78 . More surface dust concentration $2000 \mathrm{ppm}$ by mass when converted from $\mathrm{g}^{-1}$ in Table 2), as well as possible influence from glacier ice under the relatively thin snowpack $(0.3 \mathrm{~m}$ thick), could account for the lower $\rho_{\text {VIS }}$ value of 0.71 on Peyto Glacier.

A distinctive feature of rock reflectivity at Peyto Glacier base camp was $\rho_{\mathrm{NIR}}>\rho_{\mathrm{VIS}}$, a reversal from the snow and ice surfaces. This behaviour was also observed by Rott and Sogaard (1987) during spectral scans of icemarginal locations in western Greenland. For "gravel and rocks covered in lichens", their reflectivities ranged from 0.13 to 0.16 in the visible range, and 0.18 to 0.34 in the near-infrared (compared with $\rho_{\mathrm{VIS}}=0.16$ and $\rho_{\mathrm{NIR}}=$ 0.25 on Peyto Glacier moraine at solar noon).

\section{CONCLUDING REMARKS}

The results from three extreme types of ice in this study (clean, dirty and hummocked) clarify the fact that impurity content is the dominant influence on spatial variability of hemispherical reflectivity. The relatively minor difference in values between smooth and hummocked ice surfaces further emphasizes the weaker influence of roughness compared with impurity concentration. Assuming that the three selected sites do represent extreme cases of clean, dirty, rough and smooth (excluding crevassed areas), the data suggest that nearinfrared reflectivities vary only slightly over the entire ablation area of Peyto Glacier. Thus, most of the spatial variation in meltwater generation will be due to absorption of visible solar radiation. On the other hand, the overall higher absorption in the near-infrared band provides the stronger contribution to total meltwater generation by radiative melt.

Differences between clean ice (smoothest) and hummocked ice (roughest) indicate that the development of microtopography during the ablation season may reduce reflectivities. The $1 \mathrm{~m}$ hummock relief develops over a number of melt seasons. Lowering of reflectivities by up to 0.1 due to increased shading therefore represents a conservative upper constraint for a single summer.

The diurnal variability of reflectivity at all ice sites was small in comparison to the variation between ice types. In contrast to the greater fluctuation of $\rho_{\mathrm{VIS}}$ for different locations, it was $\rho_{\mathrm{NIR}}$ which displayed larger responses to temporal changes in atmospheric and surface 
conditions (also true at the snow site). This bias has also been noted in broad-band parameterizations of snow reflectivity carried out by Marshall and Warren (1987) and Marks and Dozier (1992).

The reduced reflectivities during intensive surface melt on Julian day 218 (Fig. 6), illustrate the contribution of meltwater to the low temporal variability of glacier-ice reflectivities on Peyto Glacier. Melting ice crystals at the surface have less ability to specularly reflect incident solar radiation than frozen crystals. Additionally, water-filled interstices between crystals increase the density of the surface layer, and thus reduce $\rho_{\mathrm{NIR}}$.

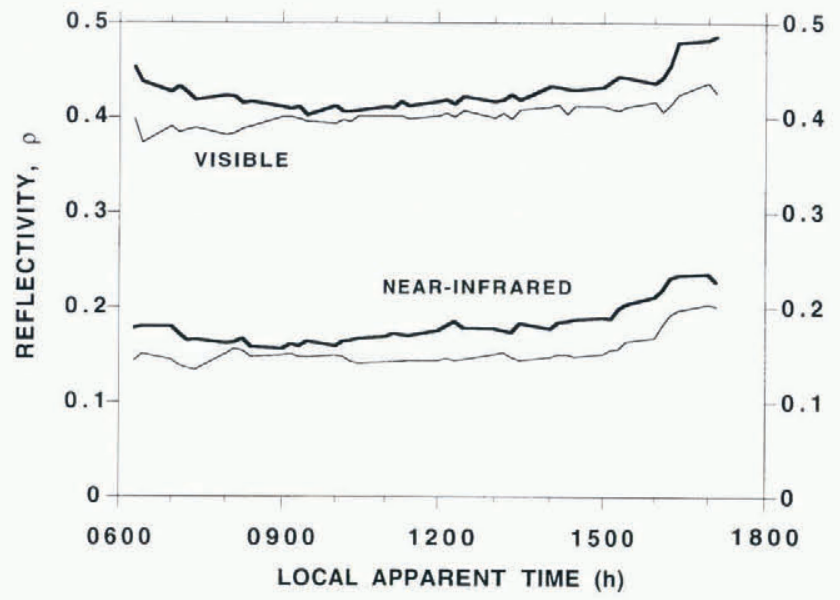

\begin{abstract}
Fig. 6. The impact of high-melt conditions for Julian day 218 (light plot) on reflectivity, illustrated by comparison with the following day of lower melt (bold plot). Sky conditions on day 218 were predominantly clear, with 0.3 cumulus cloud at all times. The next day was clear throughout.
\end{abstract}

The timing of the peak meltwater discharge at a glacier tongue will be influenced by the diurnal variation of reflectivity. Our results suggest that peak meltwater generation in the ablation area should coincide with solar noon, although other factors such as increased afternoon air temperatures, cloud presence and katabatic winds will complicate the situation.

The measurements from Peyto Glacier pose a problem for mass-balance modellers in that spatial heterogeneity of reflectivity in the visible range makes it difficult to establish correct "representative" reflectivities for altitudinal zones. Oerlemans (1990) demonstrated the possibility of a $111 \mathrm{~m}$ rise in equilibrium-line altitude due to a decrease of only 0.03 in short-wave reflectivity. Yet differences of up to 0.15 were seen between the dirty-and clean-ice locations, sites with less than $5 \mathrm{~m}$ elevation difference which would thus be grouped within the same altitudinal zone. One method of alleviating this problem might be to adopt a gridded model, whereby areas of homogeneous reflectivity are incorporated into single elements. Clearly, this approach would require detailed knowledge of reflectivity over the entire glacier at regular intervals, a feat which is practical with satellite imagery, if it is suitably processed to account for bi-directional reflectance.
The dominant influence of impurity content on spatial variation of $\rho_{\mathrm{VIS}}$ raises a question regarding the impact of impurity accumulation over time, and its effect on mass balance. The cleanest patch of ice available possessed lower $\rho_{\text {VIS }}$ than found on some glaciers, which suggests that the depositional climate may play a role in influencing mass balance. Negative mass balances have become increasingly common on Peyto Glacier in recent years: seven negative years during the 1975-85 period (Letréguilly and Reynaud, 1989). These have previously been associated with increasing temperatures alone, but the possibility that accumulating impurities have lowered the reflectivity should also be considered.

Whilst the lack of diurnal variation in reflectivity at the ice and moraine sites is in itself unexciting, this behaviour is useful from the standpoint of remote sensing. Within a $6 \mathrm{~h}$ window centred on solar noon, suitably processed satellite imagery is likely to be a reliable source of reflectivity estimates for ice, as these are within $2-3 \%$ of daily mean values, though a $4 \mathrm{~h}$ window is more appropriate for snow. Such values can be used as a base to which such factors as solar zenith-angle dependence can be added in modelling the net short-wave radiation regime of the glacier surface.

\section{ACKNOWLEDGEMENTS}

Research funding was provided by the Natural Sciences and Engineering Research Council of Canada. The authors would like to thank Parks Canada for permission to work on Peyto Glacier, and the National Hydrology Research Institute (NHRI), Environment Canada for allowing us to use their base camp facility at the glacier. The continuing NHRI programme of mass-balance assessment at Peyto is doing much to encourage associated research work such as that which is described here. Suggestions by R. LeB. Hooke on an early draft of the manuscript resulted in a number of improvements.

\section{REFERENCES}

Andrews, R.H.G. 1964. Meteorology and heat balance of the ablation area. White Glacier, Canadian Arctic Archipelago - summer 1960 (Lower Ice Station: $79^{\circ} 26^{\circ} \mathrm{N}, 90^{\circ} 39^{\prime} \mathrm{W}, 208 \mathrm{~m}$.). Montréal, Qué., McGill University. (Jacobsen-McGill Arctic Research Expedition 1959-1962. Meteorology 1. Axel Heiberg Island Research Reports.)

Bergen, J. D., B. A. Hutchinson, R. T. McMillen, A. D. Ozment and G.J. Gottfried. 1983. Observations on the relation of the shortwave reflectivity of recently deposited snow to its physical properties. $\mathcal{J}$. Climate Appl. Meteorol., 22(2), 193-200.

Bohren, C. F. and R. L. Beschta. 1979. Snowpack albedo and snow density. Cold Reg. Sci. Technol., 1 1), 47-50.

Choudhury, B.J. and A. T. C. Chang. 1981. On the angular variation of solar reflectance of snow. f. Geophys. Res., 86 Ci1), 465-472.

Colbeck, S. C. 1979. Grain clusters in wet snow. J. Colloid Interface Sci., $72(3), 371-384$.

Dozier, J. 1987. Recent research in snow hydrology. Rev, Geophys., 25 2), $153-161$.

Grenfell, T. C. and D. K. Perovich. 1984. Spectral albedos of sea ice and incident solar irradiance in the southern Beaufort Sea. 7. Geophys. Res., 89 C3), 3573-3580.

Grenfell, T. C., D. K. Perovich and J. A. Ogren. 1981. Spectral albedos of an alpine snowpack. Cold Reg. Sci. Technol., 4(2), 121-127.

Hall, D. K., R. A. Bindschadler, J. L. Foster, A. T. C. Chang and H. Siddalingaiah. 1990. Comparison of in situ and satellite-derived reflectances of Forbindels Glacier, Greenland. Int. J. Remote Sensing, $11(3), 493-504$. 
Holmgren, B. 1971. Climate and energy exchange on a sub-polar ice cap in summer. Arctic Institute of North America Devon Island Expedition 19611963. Part E. Radiation climate. Uppsala, Uppsala Universitet. (Meteorologiska Institutionen. Meddelande 111.)

Hubley, R. C. 1955. Measurements of diurnal variations in snow albedo on Lemon Creek Glacier, Alaska. J. Glaciol., 2 18), 560-563.

Letréguilly, A. and L. Reynaud. 1989. Spatial patterns of mass-balance fluctuations of North American glaciers. 7. Glaciol., 35 (120), 163-168.

McGuffie, K. and A. Henderson-Sellers. 1985. The diurnal hysteresis of snow albedo. f. Glaciol., 31(108), 188-189.

Mannstein, H. 1985. The interpretation of albedo measurements on a snow covered slope. Arch. Meteorol. Geophys. Bioklimatol., Ser. B, 36, 73-81.

Markin, V.A. 1961. Al'bedo lednikov Zemli Frantsa-Iosifa i ego rol' v radiatsionnom rezhime arkhipelaga [The albedo of the Franz Josef Land glaciers and its role in the radiation regime of the archipelago]. Akad. Nauk SSSR, Mezhd. Kom. Prov. Mezdh. Geofiz. Goda, Sbornik Statey, Ser. IX. Razdel Programmy MGG (Glyatsiologiya) 6, 111-122.

Marks, D. and J. Dozier. 1992. Climate and energy exchange at the snow surface in the alpine region of the Sierra Nevada. 2. Snow cover energy balance. Water Resour. Res., 28 (11), 3043-3054.

Marshall, S.E. and S.G. Warren. 1987. Parameterization of snow albedo for climate models. International Association of Hydrological Sciences Publication 166 (Symposium at Vancouver 1987 - Large Scale Effects of Seasonal Snow Cover), 43-50.

Mellor, M. 1977. Engineering properties of snow. J. Glaciol., 19(81), 15-66.

Monteith, J. L. 1973. Principles of environmental physics. London, Arnold.

Müller, F. and C. M. Keeler. 1969. Errors in short-term ablation measurements on melting ice surfaces. J. Glaciol., 8 (52), 91-105.

Munro, D. S. 1991. A surface energy exchange model of glacier melt and net mass balance. Int. F. Climatol., 11 (6), 689-700.

Munro, D. S. and G.J. Young. 1982. An operational net shortwave radiation model for glacier basins. Water Resour. Res., 18(2), $220-230$.

Nunez, M., J. A. Davies and P.J. Robinson. 1972. Surface albedo at a tower site on Lake Ontario. Boundary-Layer Meteorol., 3 (1), 77-86.

O'Brien, H. W. and R. H. Munis. 1975. Red and near-infrared spectral reflectance of snow. In Rango, A., ed. Operational applications of satellite snowcover operations. Washington, DC, National Aeronautics and Space Administration, 345-360. (NASA Spec. Pub. 391.

Oerlemans, J. 1990. A model for the surface balance of ice masses: Part 1 .
Alpine glaciers. Utrecht, Utrecht University. Institute for Marine and Atmospheric Research. (IMOU Research Report 90-1.)

Oerlemans, J. and N.C. Hoogendoorn. 1989. Mass-balance gradients and climatic change. F. Glaciol., 35 (121), 399 405.

Ostrem, G. and M. M. Brugman. 1991. Glacier mass balance measurements. A manual for field work. A guide for personnel with limited backgrounds in glaciology. Third edition. Saskatoon, Sask., Environment Canada. National Hydrology Research Institute. (NHRI Science Report 4.)

Rott, H. and H. Sogaard. 1987. Spectral reflectance of snow-covered and snow-free terrain in western Greenland. Z. Gletscherkd. Glazialgeol., 23 (2), 115-121.

Sauberer, F. and I. Dirmhirn. 1952. Der Strahlungshaushalt horizontaler Gletscherflächen auf dem hohen Sonnblick. Geogr. Ann., 34 (34), 261-290.

Scheibbner, F. and W. Mahringer. 1968. Die Albedo der Sonnblickgletscher und ihre zeitlichen Variationen. Arch. Meteorol. Geophys. Bioklimatol., Ser. B, 16 2-3), 174-194.

Schwerdtfeger, P. 1976. Physical principles of micrometeorological measurements. Amsterdam, Elsevier. (Developments in Atmospheric Science 6.)

Siegel, R. and J. R. Howell. 1972. Thermal radiation heat transfer. New York, McGraw-Hill.

Wagner, H.P. 1979. Strahlungshaushaltsuntersuchungen an einem Östalpengletscher während der Hauptablationsperiode. Arch. Meteorol. Geophys. Bioklimatol., Ser. B, $27(4), 325-333$.

Warren, S. G. 1982. Optical properties of snow. Rev. Geophys. Space Phys., 20 (1), 67-89.

Weiss, A. and J. M. Norman. 1985. Partitioning solar radiation into direct and diffuse visible and near-infrared components. Agricultural and Forest Meteorology, 34, $205-213$.

Wendler, G. and J. Kelley, 1988. On the albedo of snow in Antarctica: a contribution to I.A.G.O. J. Glaciol., 34(116), 19-25.

Wendler, G. and G. Weller. 1974. A heat-balance study on McCall Glacier, Brooks Range, Alaska: a contribution to the International Hydrological Decade. 7. Glaciol., $13(67), 13-26$.

Yamanouchi, T. 1983. Variations of incident solar flux and snow albedo on the solar zenith angle and cloud cover, at Mizuho Station, Antarctica. 7. Meteorol. Soc. Jpn, 61 (6), 879 893.

Zeng, Q., M. Cao, M. Feng, F. Liang, X. Chen and F. Sheng. 1984. Study of spectral reflection characteristics of snow, ice and water of northwest China. Sci. Sin., Ser.B, $27(6), 647-656$. 